Portland State University

PDXScholar

TREC Final Reports

Transportation Research and Education Center

(TREC)

$5-2015$

2014 Transit Oriented Developments Survey

Jennifer Dill

Portland State University, jdill@pdx.edu

Nathan McNeil

Portland State University

Follow this and additional works at: https://pdxscholar.library.pdx.edu/trec_reports

Part of the Transportation Commons, Urban Studies Commons, and the Urban Studies and Planning Commons

Let us know how access to this document benefits you.

Recommended Citation

Dill, Jennifer and McNeil, Nathan. 2014 Transit Oriented Developments Survey. TREC-15-01. Portland, OR: Transportation Research and Education Center (TREC), 2015. http://dx.doi.org/10.15760/trec.74

This Report is brought to you for free and open access. It has been accepted for inclusion in TREC Final Reports by an authorized administrator of PDXScholar. Please contact us if we can make this document more accessible: pdxscholar@pdx.edu. 


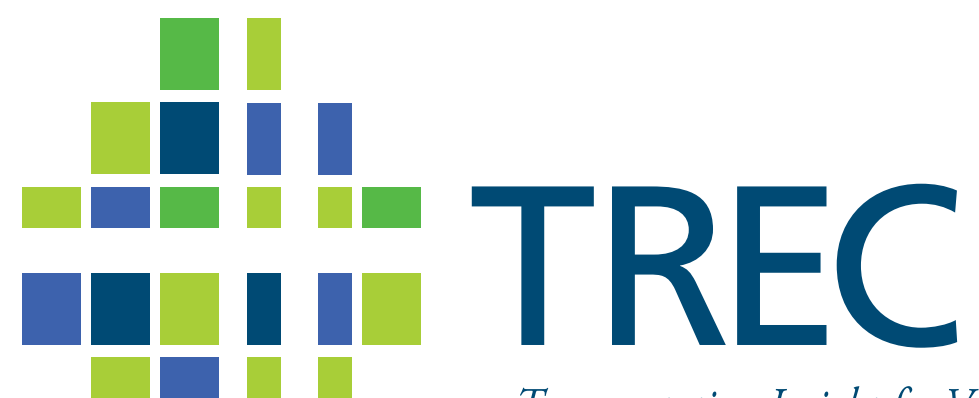

Transportation Insight for Vibrant Communities

FINAL REPORT

2014 Transit Oriented Developments Survey

TREC-15-01 $\mathbf{\square}$ May 2015

TREC is the Transportation Research and Education Center at Portland State University. 


\section{Portland State}

May 6, 2015

TO: $\quad$ Jon Williams, Metro

FROM: Jennifer Dill, Ph.D. Nathan McNeil

RE: $\quad$ Findings from 2014 TOD Surveys

\section{Introduction}

This report presents results from surveys of residents at several transit-oriented developments (TODs) in Portland, Hillsboro, Tigard, and unincorporated Clackamas County. The research complements our previous survey work for Metro done at eight TODs in 2010 and 11 TODs in 2007. TODs included in this study are shown in Table 1. Findings of a related survey of the non-residential Globe Buildings, housing the Oregon College or Oriental Medicine, are presented in a separate report.

Table 1: TODs included in study

\begin{tabular}{|l|c|c|c|c|l|l|}
\hline & $\begin{array}{c}\text { \# of } \\
\text { units }\end{array}$ & $\begin{array}{c}\text { Affordable } \\
\text { units }\end{array}$ & $\begin{array}{c}\text { Senior } \\
\text { units }\end{array}$ & $\begin{array}{l}\text { Date } \\
\text { built }\end{array}$ & Transit & Transit Station \\
\hline $\begin{array}{l}\text { Acadia } \\
\text { Gardens }\end{array}$ & 41 & 41 & 0 & 2012 & Light Rail & $\begin{array}{l}\text { Clackamas Town Center, } \\
\text { Clackamas County }\end{array}$ \\
\hline $\begin{array}{l}\text { Central } \\
\text { Eastside Lofts }\end{array}$ & 70 & 0 & 0 & 2012 & $\begin{array}{l}\text { Light Rail/ } \\
\text { Streetcar }\end{array}$ & $\begin{array}{l}\text { SE Grand \& E Burnside } \\
\text { (Streetcar), Portland }\end{array}$ \\
\hline $\begin{array}{l}\text { Hollywood } \\
\text { Apartments }\end{array}$ & 47 & 10 & 0 & 2013 & Light Rail & $\begin{array}{l}\text { Hollywood/NE 42nd } \\
\text { Ave Transit Center, } \\
\text { Portland }\end{array}$ \\
\hline K Station & 54 & 33 & 0 & 2011 & Light Rail & $\begin{array}{l}\text { N Killingsworth St, } \\
\text { Portland }\end{array}$ \\
\hline Milano & 60 & 0 & 0 & 2012 & $\begin{array}{l}\text { Light } \\
\text { Rail/Bike }\end{array}$ & $\begin{array}{l}\text { Rose Quarter Transit } \\
\text { Center, Portland }\end{array}$ \\
\hline Pettygrove & 95 & 0 & 0 & 2012 & Streetcar & $\begin{array}{l}\text { NW 21st \& Northrup } \\
\text { (Streetcar), Portland }\end{array}$ \\
\hline The Knoll & 48 & 48 & 48 & 2010 & Bus & $\begin{array}{l}\text { Tigard Transit Center, } \\
\text { Tigard }\end{array}$ \\
\hline The Prescott & 155 & 31 & 0 & 2013 & Light Rail & N Prescott St, Portland \\
\hline 4th Main & 71 & 0 & 0 & 2014 & Light Rail & Hillsboro Central \\
\hline $\begin{array}{l}\text { University } \\
\text { Pointe }\end{array}$ & $\begin{array}{l}287 \\
(900 \\
\text { beds) }\end{array}$ & 0 & 0 & 2012 & Light Rail & SW 5th \& Hall, Portland \\
\hline
\end{tabular}




\section{Methodology}

To allow comparison across the region, the surveys were conducted in roughly the same manner as in 2005, 2007, and 2010 with a very similar survey instrument. This year's survey was shorter, based upon feedback from Metro staff. The eight-page survey included the following sections:

- Information on your Household. This included questions on household size and number of vehicles.

- Information about up to ten trips taken on the most recent Tuesday.

- Frequency of walking or bicycling and taking transit to common non-work destinations in good weather.

- Changes in daily travel compared to previous residence.

- Information on your Place of Work/School and Commuting.

- Information on Commuting from your Prior Residence

- Information on your Current Place of Residence. This section focused on the importance of various items in selecting their home.

- Information on your Travel Preferences. This section attempts to gauge people's preferences for various modes.

- Typical miles driven in a week and changes in vehicle ownership resulting from characteristics of their current neighborhood.

- Information about you. This section includes standard demographic questions and some questions about mobility impairments.

Each survey packet generally included two questionnaires (one for each potential adult in the household), a cover letter, and postage-paid return envelope. Respondents were asked to recycle extra forms. In the case of two buildings (The Knoll and The Prescott), the building manager provided the number of adults residing in each unit, and so the exact number of surveys were provided in those cases. Each letter also included a link to an online version of the survey, for residents preferring to take the survey electronically. Exceptions to this were the Knoll, for which an electronic survey option was not included, and University Pointe, which was conducted entirely electronically. University Pointe residents were given postcards explaining the study and directing them to the online survey, and via email reminders with the link. 
In buildings with an onsite building manager, the building manager was provided with $\$ 5$ gift cards to a local merchant (which included Starbucks, Ristretto Roasters, and New Seasons), and provided the gift card to residents as compensation when they submitted a completed survey. In several cases without onsite building managers (e.g. K Station and The Hollywood), the compensation consisted of entering a drawing for one of five $\$ 50$ Amazon.com gift cards per building. For all of the developments, we conducted a second mailing to non-respondents. To boost responses, an additional \$100 Amazon.com gift card was provided to the winner of a drawing across several buildings among people completing their surveys after the previously stated deadline. Because of the large number of residents in University Pointe, a drawing for one of ten $\$ 50$ Amazon.com gift cards was conducted, and a follow-up compensation offering of a $\$ 10$ Starbucks gift card was provided to the first 20 completions on the final day of data collection for that site.

Sample sizes and response rates are in Table 2 . The overall response rate is $35 \%$ among standard residential buildings in the study, and $12 \%$ in University Pointe (focused toward student residents). This response rate is in line with the 2010 data collection (35\%), both of which are higher than in 2005 (29\%) and 2007 (26\%). Response rates for individual developments ranged from $22 \%$ to $59 \%$. 
Table 2: Response rates

\begin{tabular}{|c|c|c|c|c|c|}
\hline & $\begin{array}{l}\text { \# units in } \\
\text { survey }\end{array}$ & \# vacant & $\begin{array}{l}\text { \# of units } \\
\text { responding }\end{array}$ & $\begin{array}{l}\text { Response } \\
\text { rate }\end{array}$ & $\begin{array}{l}\text { \# Individual } \\
\text { Surveys } \\
\text { Completed }\end{array}$ \\
\hline Acadia Gardens & 41 & 1 & 12 & $30 \%$ & 18 \\
\hline $\begin{array}{l}\text { Central Eastside } \\
\text { Lofts }\end{array}$ & 70 & 5 & 17 & $26 \%$ & 27 \\
\hline $\begin{array}{l}\text { Hollywood } \\
\text { Apartments }\end{array}$ & 47 & 1 & 16 & $35 \%$ & 17 \\
\hline $\begin{array}{l}\text { Killingsworth } \\
\text { Station (K Station) }\end{array}$ & 54 & 0 & 32 & $59 \%$ & 39 \\
\hline Milano & 60 & 6 & 21 & $39 \%$ & 26 \\
\hline Pettygrove & 95 & 3 & 20 & $22 \%$ & 26 \\
\hline The Knoll & 48 & 0 & 24 & $50 \%$ & 27 \\
\hline The Prescott & 155 & 5 & 49 & $33 \%$ & 60 \\
\hline 4th Main & 71 & 22 & 11 & $22 \%$ & 11 \\
\hline Sub-total & 641 & 43 & 202 & $\begin{array}{l}34 \% \text { overall } \\
35 \% \text { average }\end{array}$ & 251 \\
\hline University Pointe & 900 & $?$ & 109 & $12 \%$ & 109 \\
\hline Total & 1541 & 43 & 301 & $\begin{array}{r}20 \% \text { overall } \\
33 \% \text { average }\end{array}$ & 360 \\
\hline
\end{tabular}

${ }^{a}$ Most survey packets included two surveys, one for each potential adult resident. Therefore, the total number of surveys completed may be higher than the number of units responding.

\section{Findings}

\section{Trip Generation}

One section of the survey asked about trips made for the most recent Tuesday. The intent of this question is to generate a "trip generation" rate for each person. The survey mailings were timed to arrive on Tuesday or Wednesday so as to maximize accuracy in recall. The first two trips were captured using the questions shown below. Similar information was collected for up to eight additional trips using similar question wording. 
We are interested in learning about how you get around during the day. For the next few questions, we are particularly interested in trips you made on Tuesday of this week.

If you were out of town on Tuesday of this week, you may answer the questions for another day of the week. Please indicate the day here:

1. On Tuesday of this week, the first time you left your home, where were you going?
$1 \square$ To work
$2 \square$ To school (as a student)
$3 \square$ Shopping, errands, or eating out
$4 \square$ Visiting friends or family
${ }_{9} \square$ I did not go anywhere on Tuesday. Please skip to Question 7 on page 3.
$5 \square$ Taking someone else someplace (e.g. child to school)
$6 \square$ Entertainment or exercise
$7 \square$ No particular destination (ex: a jog, stroll, or walking a dog)
$8 \square$ Other:

2. How did you get there?
$1 \square$ Drove alone
${ }_{2} \square$ Drove or rode with someone else
${ }_{6} \square$ Streetcar
$3 \square$ Walked
$4 \square$ Bicycled
$5 \square$ MAX
$5 \square$ MAX
$8 \square$ TriMet LIFT service or RideConnection
$9 \square$ Other:
3. Consider where you went after that. Where were you going?
$1 \square$ Home
${ }_{2} \square$ To work
$3 \square$ To school (as a student)
$4 \square$ Shopping, errands, or eating out
$5 \square$ Visiting friends or family

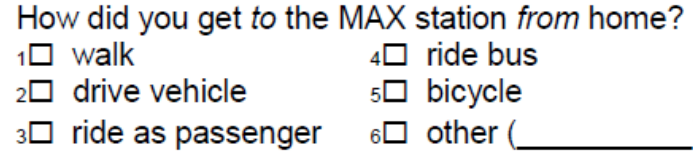
6 Taking someone else someplace (e.g. child to school)
$7 \square$ Entertainment or exercise
$8 \square$ No particular destination (ex: a jog, stroll, or walking a dog)
$9 \square$ Other:

4. How did you get there?

$1 \square$ Drove alone

${ }_{2} \square$ Drove or rode with someone else

${ }_{6} \square$ Streetcar

$\square$ TriMet Lif

$9 \square$ Other:

The results are shown in Table 3 and Table 4 . Table 3 present the data for all trips, including home-based (starting at home) and non-home based trips. Table 4 presents the information just for trips starting from home (home-based trips). These data are used to estimate a personal motor vehicle trip generation rate per unit, shown in Table 5. For the trip generation estimate, the respondent is assumed to have returned home by the mode they departed, and carpool trips are adjusted down to account for the carpool trips that were reported by respondents in the same household. 
Table 3: Total Trips Per Person

\begin{tabular}{|c|c|c|c|c|c|c|c|}
\hline & $\begin{array}{c}\text { Total } \\
\text { trips } \\
\text { (mean) }\end{array}$ & $\begin{array}{c}\text { Total } \\
\text { transit trips } \\
\text { (mean) }\end{array}$ & $\begin{array}{l}\text { Transit } \\
\text { Share }\end{array}$ & $\begin{array}{c}\text { Total SOV } \\
\text { trips } \\
\text { (mean) }\end{array}$ & $\begin{array}{c}\text { Total } \\
\text { Carpool trips } \\
\text { (mean) }\end{array}$ & $\begin{array}{c}\text { Total Walk } \\
+ \text { Bike Trips } \\
\text { (mean) }\end{array}$ & $\mathbf{n}$ \\
\hline $\begin{array}{l}\text { Acadia } \\
\text { Gardens }\end{array}$ & 2.8 & 0.3 & $10 \%$ & 1.4 & 0.4 & 0.4 & 18 \\
\hline $\begin{array}{l}\text { Central } \\
\text { Eastside Lofts }\end{array}$ & 3.4 & 0.6 & $17 \%$ & 1.0 & 0.7 & 1.1 & 27 \\
\hline $\begin{array}{l}\text { Hollywood } \\
\text { Apartments }\end{array}$ & 4.1 & 0.6 & $14 \%$ & 1.7 & 0.4 & 1.2 & 17 \\
\hline K Station & 2.7 & 0.3 & $10 \%$ & 1.1 & 0.3 & 0.9 & 39 \\
\hline The Knoll & 1.9 & 0.1 & $8 \%$ & 0.8 & 0.3 & 0.5 & 27 \\
\hline Milano & 3.7 & 1.0 & $28 \%$ & 0.7 & 0.3 & 1.3 & 26 \\
\hline Pettygrove & 3.1 & 0.3 & $10 \%$ & 1.8 & 0.1 & 0.8 & 26 \\
\hline The Prescott & 2.9 & 0.4 & $13 \%$ & 1.5 & 0.3 & 0.6 & 60 \\
\hline 4th Main & 3.0 & 0.7 & $23 \%$ & 1.0 & 0.6 & 0.6 & 11 \\
\hline $\begin{array}{l}\text { University } \\
\text { Pointe }\end{array}$ & 3.3 & 0.9 & $28 \%$ & 0.1 & 0.1 & 2.0 & 109 \\
\hline All TODs & 3.1 & 0.6 & $19 \%$ & 0.9 & 0.3 & 1.2 & 360 \\
\hline $\begin{array}{l}\text { All TODs, } \\
\text { except } \\
\text { University } \\
\text { Pointe }\end{array}$ & 3.0 & 0.4 & $14 \%$ & 1.2 & 0.4 & 0.8 & 251 \\
\hline
\end{tabular}


Table 4: Trips from Home Per Person

\begin{tabular}{|l|c|c|c|c|c|c|c|}
\hline & $\begin{array}{c}\text { Home } \\
\text { Based Trips } \\
\text { (mean) }\end{array}$ & $\begin{array}{c}\text { Home-based } \\
\text { transit trips } \\
\text { (mean) }\end{array}$ & $\begin{array}{c}\text { Transit } \\
\text { share }\end{array}$ & $\begin{array}{c}\text { Home-based } \\
\text { SOV trips } \\
\text { (mean) }\end{array}$ & $\begin{array}{c}\text { Home-based } \\
\text { Carpool trips } \\
\text { (mean) }\end{array}$ & $\begin{array}{c}\text { Home-based } \\
\text { Walk + Bike } \\
\text { Trips (mean) }\end{array}$ & $\mathbf{n}$ \\
\hline Acadia Gardens & 1.3 & 0.2 & $17 \%$ & 0.7 & 0.2 & 0.2 & 18 \\
\hline $\begin{array}{l}\text { Central Eastside } \\
\text { Lofts }\end{array}$ & 1.5 & 0.3 & $19 \%$ & 0.3 & 0.3 & 0.6 & 27 \\
\hline $\begin{array}{l}\text { Hollywood } \\
\text { Apartments }\end{array}$ & 1.6 & 0.2 & $14 \%$ & 0.6 & 0.2 & 0.6 & 17 \\
\hline K Station & 1.2 & 0.1 & $11 \%$ & 0.5 & 0.1 & 0.5 & 39 \\
\hline The Knoll & 1.0 & 0.1 & $7 \%$ & 0.4 & 0.1 & 0.4 & 27 \\
\hline Milano & 1.8 & 0.5 & $30 \%$ & 0.3 & 0.1 & 0.7 & 26 \\
\hline Pettygrove & 1.6 & 0.2 & $10 \%$ & 0.8 & 0.04 & 0.6 & 26 \\
\hline The Prescott & 1.4 & 0.2 & $17 \%$ & 0.7 & 0.2 & 0.3 & 60 \\
\hline 4th Main & 1.4 & 0.4 & $29 \%$ & 0.4 & 0.1 & 0.4 & 11 \\
\hline University Pointe & 1.5 & 0.4 & $25 \%$ & 0.04 & 0.02 & 1.1 & 109 \\
\hline All TODs & 1.5 & 0.3 & $19 \%$ & 0.4 & 0.1 & 0.6 & 360 \\
\hline $\begin{array}{l}\text { All TODs, except } \\
\text { University Pointe }\end{array}$ & 1.4 & 0.2 & $17 \%$ & 0.5 & 0.2 & 0.4 & 251 \\
\hline
\end{tabular}


Table 5: Estimated Home-based Personal Motor Vehicle Trips Per Unit

\begin{tabular}{|c|c|c|c|c|c|c|}
\hline Building & $\begin{array}{c}\text { \# of } \\
\text { responding } \\
\text { residents }\end{array}$ & $\begin{array}{c}\text { Total personal } \\
\text { vehicle trips from } \\
\text { home reported }^{\mathrm{a}}\end{array}$ & $\begin{array}{l}\text { \# of } \\
\text { units }\end{array}$ & $\begin{array}{c}\text { Estimated } \\
\text { Trips per } \\
\text { unit }\end{array}$ & $\begin{array}{c}\text { ITE Trip } \\
\text { Rate }^{c}\end{array}$ & $\begin{array}{c}\text { Percent } \\
\text { of ITE } \\
\text { Trips }\end{array}$ \\
\hline $\begin{array}{l}\text { Acadia } \\
\text { Gardens }\end{array}$ & 18 & 15 & 12 & 2.5 & 4.2 & $60 \%$ \\
\hline $\begin{array}{l}\text { Central } \\
\text { Eastside } \\
\text { Lofts }\end{array}$ & 27 & 14 & 17 & 1.6 & 4.2 & $38 \%$ \\
\hline $\begin{array}{l}\text { Hollywood } \\
\text { Apartments }\end{array}$ & 17 & 14 & 16 & 1.8 & 4.18 & $43 \%$ \\
\hline K Station & 39 & 21 & 32 & 1.3 & 4.18 & $31 \%$ \\
\hline The Knoll & 27 & 13 & 24 & 1.1 & 3.4 & $32 \%$ \\
\hline Milano & 26 & 12 & 21 & 1.1 & 4.2 & $26 \%$ \\
\hline Pettygrove & 26 & 23 & 20 & 2.3 & 4.2 & $55 \%$ \\
\hline $\begin{array}{l}\text { The } \\
\text { Prescott }\end{array}$ & 60 & 51 & 49 & 2.1 & 4.2 & $50 \%$ \\
\hline $4^{\text {th }}$ Main & 11 & 5 & 11 & 0.9 & 4.2 & $21 \%$ \\
\hline $\begin{array}{l}\text { University } \\
\text { Pointe }\end{array}$ & 109 & 6 & $35^{b}$ & 0.3 & 4.2 & $2 \%$ \\
\hline Total & 360 & 174 & 237 & 1.5 & & \\
\hline $\begin{array}{l}\text { All but } \\
\text { University } \\
\text { Pointe } \\
\end{array}$ & & 168 & 202 & 1.7 & & \\
\hline
\end{tabular}

${ }^{a}$ Carpool trips are carpool trips are adjusted down to account for the carpool trips that were reported by respondents in the same household.

${ }^{b}$ University Pointe rents beds to individuals, rather than units to groups of residents. There are an average of 3.14 beds per unit. Therefore, we estimate that the 109 respondents represent approximately 35 units.

${ }^{\mathbf{c}}$ ITE Trip Rate is from the Trip Generation Manual, $9^{\text {th }}$ Edition, 2012. Trip Rates for Mid Rise Apartments utilitze ITE daily rates for High Rise Apartments due to the lack of an ITE daily rate for Mid Rise Apartments, and the relative parity between High Rise and Mid Rise Apartments for AM and PM peak trip rates.

Overall, the residents at buildings other than University Pointe generated about 1.7 vehicle trips per unit on the weekday examined. This includes trips leaving and coming (to and from) home. The results show considerable variation between the TODs, perhaps due to some small sample sizes (e.g. Acadia Gardens and $4^{\text {th }}$ Main), where the means can be influenced by high or low values. Other facilities, like the Knoll, may be less likely to generate trips due to their population (i.e. mostly senior residents in the case of the Knoll). University Pointe, with a largely student population, generated very few motor vehicle trips, and was much lower than all other TODs surveyed. 
The overall trip rate could be compared to the ITE rates and other rates used to estimate vehicle travel generated by a development. The number from the survey will be slightly lower than reality, due to trips generated by non-residents, e.g. non-residents visiting residents and trips made by project employees. However, these are likely to be a small number of trips. The rate of 1.7 trips per unit (excluding University Pointe) is significantly lower than the rate Metro uses from the ITE Trip Generation book (about 6.6 trips per apartment) and lower than the rate estimated from the TOD surveys conducted in 2010 (2.8). The difference from 2010 appears to be due to (1) fewer total trips reported leaving home and (2) fewer motor vehicle trips from home. Why the residents of these TODs would be reporting fewer trips from home than the TODs in the 2010 survey is unclear. It could be due to differences in survey methodology or differences in demographics or trip-chaining patterns.

The ITE Trip Generation Manual (9 $9^{\text {th }}$ Edition, 2012) does break down residential buildings beyond the general "apartment" category, with its estimate of 6.6 trips per unit per day. The breakdowns for the best comparable land uses to the study buildings, including High Rise Apartments (4.2 daily trips), Mid Rise Apartments (no daily rate given, but hourly rates are comparable to High Rise Apartments), High Rise Condominiums (4.18 daily trips), and Senior Adult Attached Housing (3.44 daily trips), are all considerably lower than the general apartment rate of 6.6 daily trips. Still, these breakdowns do not provide adjustment for TOD characteristics, including transit access and mixed-use. (Please see the Appendix for additional analysis of the ITE rates.)

A 2008 Transit Cooperative Research Program (TCRP) report ${ }^{1}$ on the effects of TODs observed that TOD vehicle trip rates are considerably lower than the standard ITE rate for apartments. Rates for Portland TODs in that report ranged from $13 \%$ to $94 \%$ of the ITE rates, with a mean of $59 \%$. TOD trip generation rates for other cities were also lower than the ITE rates: $52 \%$ of the ITE rate for San Francisco, 37\% of the rate for Washington DC, and $73 \%$ of the rate for Philadelphia area TODs (pg. 37). Excluding University Pointe, our estimated trip generation rates for the TODs in this study ranged from $21 \%$ to $60 \%$ of the ITE daily trip rates for the comparable type of development (e.g. high-rise apartment, senior living, etc.), with a mean of $40 \%$. This difference is, therefore, comparable to the differences found in the TCRP study.

In addition to the undercounting of non-resident trips mentioned above, the lower rate (compared to ITE) may also be due to people underreporting trips. There is no reason to believe that the respondents would systematically underreport (or over-report) their trips on

\footnotetext{
${ }^{1}$ Arrington, G.B. and R. Cervero. TCRP 128: Effects of TOD on Housing, Parking, and Travel. Transit Cooperative Research Program, Transportation Research Board of the National Academies, Washington, D.C.: 2008.
} 
the survey form, but there is no way to know for sure. Respondents might over-report transit trips if they thought that response would be viewed favorably by the researchers or other users of the data. It is not possible to know whether this occurred in this case. Respondents may also forget about trips, which would result in an underestimate. However, these factors are unlikely to account for all of the difference between the estimated rates and the ITE rates.

Much of the difference is likely due to increased use of alternative modes, compared to the apartments sampled by ITE. From the trips reported, we estimated the mode split for all trips leaving the TODs (Figure 1). About 55\% of all trips were made in personal vehicles. This is significantly lower than the 2008-09 National Household Travel Survey (NHTS), where about $84 \%$ of all trips were made in personal vehicles. In addition, $17 \%$ of the TOD resident trips were made on either MAX, Streetcar, TriMet buses, or categorized as "other" (which were usually forms of transit, including TriMet LIFT and other paratransit-type service). This compares to about $4 \%$ of trips reported in the NHTS.

\section{Mode Split}

The mode split for all trips is shown in Figure 1. Overall, only 39\% of all trips were made in personal motor vehicles (driving alone or carpool). Removing University Pointe from the calculations, $55 \%$ of the trips were made in personal motor vehicles, $20 \%$ by foot, $15 \%$ by regular, fixed-route transit, and $8 \%$ by bicycle.

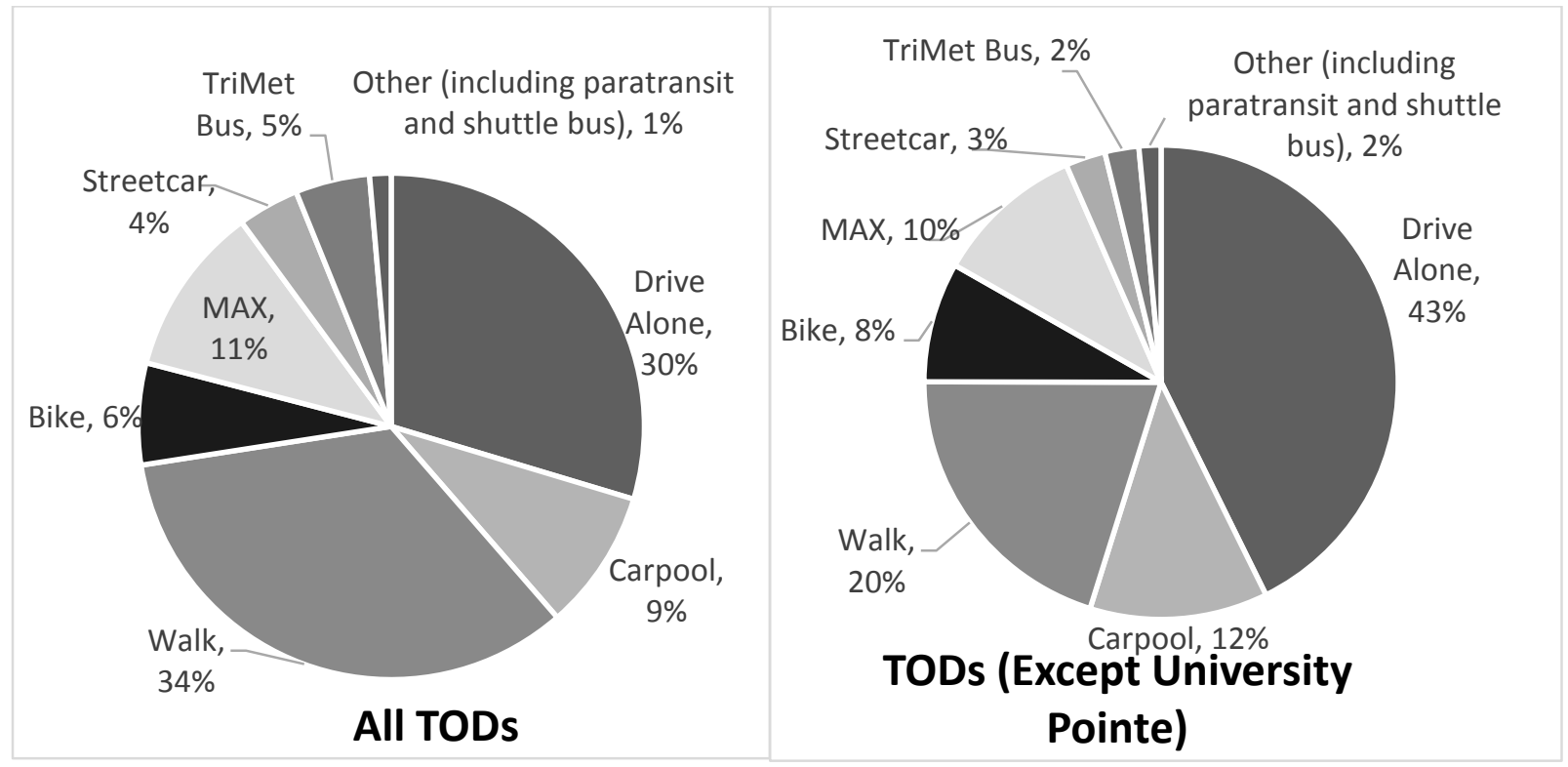

Figure 1: Mode Split for All Reported Trips 
Vehicle availability, which is related to income, appears to explain some of these travel patterns. Most of the households had at least one vehicle (Table 6). Adult respondents living in households with one or more vehicles per person of driving age were far less likely to use transit (Table 7).

Table 6: Vehicle availability

\begin{tabular}{|l|c|l|c|}
\hline \multicolumn{2}{|c|}{ All except University Pointe } & \multicolumn{2}{c|}{ University Pointe } \\
\hline 0 & $16 \%$ & Have Car & $16 \%$ \\
\hline 1 & $58 \%$ & Have Access & $10 \%$ \\
\hline 2 & $24 \%$ & No & $74 \%$ \\
\hline $3+$ & $3 \%$ & $\mathrm{n}$ & 109 \\
\hline $\mathrm{n}$ & 250 & & \\
\hline
\end{tabular}

Table 7: Vehicle availability and mode split

\begin{tabular}{|l|c|c|c|c|}
\hline & \multicolumn{2}{|c|}{ All TODs } & \multicolumn{2}{c|}{ Excluding University Pointe } \\
\hline & $\begin{array}{c}\text { Less than one } \\
\text { vehicle per } \\
\text { person 16+ }\end{array}$ & $\begin{array}{c}\text { One or more } \\
\text { vehicles per } \\
\text { person 16+ }\end{array}$ & $\begin{array}{c}\text { Less than one } \\
\text { vehicle per } \\
\text { person 16+ }\end{array}$ & $\begin{array}{c}\text { One or more } \\
\text { vehicles per } \\
\text { person 16+ }\end{array}$ \\
\hline Private Vehicles & $15 \%$ & $64 \%$ & $29 \%$ & $68 \%$ \\
\hline Foot/Bike & $53 \%$ & $25 \%$ & $38 \%$ & $21 \%$ \\
\hline Transit & $29 \%$ & $8 \%$ & $29 \%$ & $6 \%$ \\
\hline $\mathrm{n}$ & 180 & 178 & 88 & 161 \\
\hline
\end{tabular}

\section{Commute Mode}

\section{Current Commute Mode}

Another section of the survey asked specifically about commuting to work or school. Overall, $61 \%(n=215)$ of the respondents do work or go to school outside of the home. Of these, $27 \%$ used MAX or the Streetcar to get to work or school 4-5 days per week and 12\% took the bus that often (Table 8). Only $28 \%$ of the respondents drove alone $4-5$ days per week. The numbers do shift when University Pointe is removed (Table 9), with $40 \%$ driving along 4-5 days a week.

Of the respondents who currently commute by MAX or Streetcar ( $n=135), 94.5 \%$ walked or biked to the station, $3 \%$ took the bus, and $1.5 \%$ drove. 
Table 8: Commute modes, all TODs Surveyed

\begin{tabular}{|l|c|c|c|c|c|c|c|}
\hline & $\begin{array}{c}\text { 4-5 days } \\
\text { per week }\end{array}$ & $\begin{array}{c}\mathbf{2 - 3} \text { days } \\
\text { per week }\end{array}$ & $\begin{array}{c}\text { Once } \\
\text { a week }\end{array}$ & $\begin{array}{c}\text { 1-3 days } \\
\text { a month }\end{array}$ & $\begin{array}{c}\text { Less than } \\
\text { once a } \\
\text { month }\end{array}$ & Never & n \\
\hline Drive alone & $28 \%$ & $10 \%$ & $6 \%$ & $5 \%$ & $6 \%$ & $45 \%$ & 258 \\
\hline Carpool & $5 \%$ & $5 \%$ & $4 \%$ & $7 \%$ & $5 \%$ & $75 \%$ & 244 \\
\hline MAX light rail & $21 \%$ & $9 \%$ & $8 \%$ & $6 \%$ & $6 \%$ & $49 \%$ & 247 \\
\hline Streetcar & $5 \%$ & $4 \%$ & $9 \%$ & $5 \%$ & $9 \%$ & $67 \%$ & 241 \\
\hline TriMet bus & $12 \%$ & $5 \%$ & $6 \%$ & $6 \%$ & $8 \%$ & $63 \%$ & 246 \\
\hline Walk & $35 \%$ & $6 \%$ & $7 \%$ & $6 \%$ & $2 \%$ & $44 \%$ & 246 \\
\hline Bicycle & $7 \%$ & $3 \%$ & $6 \%$ & $6 \%$ & $7 \%$ & $72 \%$ & 243 \\
\hline
\end{tabular}

Table 9: Commute Modes, all TODs except University Pointe

\begin{tabular}{|l|c|c|c|c|c|c|c|}
\hline & $\begin{array}{c}\text { 4-5 days } \\
\text { per week }\end{array}$ & $\begin{array}{c}\mathbf{2 - 3} \text { days } \\
\text { per week }\end{array}$ & $\begin{array}{c}\text { Once } \\
\text { a week }\end{array}$ & $\begin{array}{c}\mathbf{1 - 3} \text { days } \\
\text { a month }\end{array}$ & $\begin{array}{c}\text { Less than } \\
\text { once a } \\
\text { month }\end{array}$ & Never & n \\
\hline Drive alone & $40 \%$ & $13 \%$ & $7 \%$ & $6 \%$ & $7 \%$ & $27 \%$ & 171 \\
\hline Carpool & $6 \%$ & $5 \%$ & $3 \%$ & $5 \%$ & $4 \%$ & $76 \%$ & 158 \\
\hline MAX light rail & $21 \%$ & $8 \%$ & $2 \%$ & $5 \%$ & $8 \%$ & $57 \%$ & 159 \\
\hline Streetcar & $5 \%$ & $1 \%$ & $3 \%$ & $3 \%$ & $8 \%$ & $81 \%$ & 155 \\
\hline TriMet bus & $10 \%$ & $3 \%$ & $3 \%$ & $3 \%$ & $6 \%$ & $75 \%$ & 158 \\
\hline Walk & $18 \%$ & $4 \%$ & $5 \%$ & $7 \%$ & $3 \%$ & $62 \%$ & 158 \\
\hline Bicycle & $8 \%$ & $4 \%$ & $6 \%$ & $5 \%$ & $6 \%$ & $70 \%$ & 157 \\
\hline
\end{tabular}

TOD respondents' primary commute mode was calculated based on the most frequently reported use of each of the modes listed in Table 8 and Table 9 (if two or more modes were tied for most frequently used, the respondent was marked as "combination or other"). Table 10 shows the primary mode of respondents compared to the 2009-2013 American Community Survey (ACS) primary mode of transportation to work of residents in the cities in which the TODs are located: Hillsboro, Portland, and Tigard. Because Acadia Gardens is in unincorporated Clackamas County, its zip code, 97086, containing portions of unincorporated Clackamas County and Happy Valley, is included for comparison. Use of motor vehicles was much lower among TOD residents than any of the overall cities, while transit and active transportation modes were generally higher. 
Table 10: Primary Mode, all TODs except University Pointe, compared to ACS 2009-2013 data

\begin{tabular}{|l|c|c|c|c|c|}
\hline & \multirow{2}{*}{$\begin{array}{c}\text { TODs, excluding } \\
\text { University Pointe }\end{array}$} & $\begin{array}{c}\text { Zipcode 97086 } \\
\text { (Clackamas \& } \\
\text { Happy Valley) }\end{array}$ & Hillsboro & Portland & Tigard \\
\hline Drove alone & $53 \%$ & $82 \%$ & $76 \%$ & $64 \%$ & $78 \%$ \\
\hline Carpooled: & $26 \%$ & $11 \%$ & $11 \%$ & $10 \%$ & $12 \%$ \\
\hline Public transportation & $13 \%$ & $4 \%$ & $7 \%$ & $13 \%$ & $6 \%$ \\
\hline Walk/Bike & $8 \%$ & $2 \%$ & $4 \%$ & $13 \%$ & $4 \%$ \\
\hline Combination & 236 & & & & \\
\hline $\mathrm{n}$ & & & & \\
\hline
\end{tabular}

The price of parking at school or work effects people's commute mode choice. Of the respondents that would have to pay for parking at school or work, only $12 \%$ usually used a private vehicle to get to work (Table 11). In contrast, $60 \%$ of those that do not have to pay to park used a private vehicle. The respondents that would have to pay to park are likely working or going to school downtown or in the Lloyd District, also very convenient locations to reach by transit from many of these TODs.

Table 11: Commute mode and parking cost

\begin{tabular}{|l|c|c|}
\hline & $\begin{array}{c}\text { Would have to } \\
\text { pay to park }\end{array}$ & $\begin{array}{c}\text { Would not } \\
\text { have to pay to } \\
\text { park }\end{array}$ \\
\hline Private vehicle & $12 \%$ & $60 \%$ \\
\hline Transit & $44 \%$ & $22 \%$ \\
\hline Walk/Bike & $34 \%$ & $10 \%$ \\
\hline Other or combination & $10 \%$ & $8 \%$ \\
\hline $\mathrm{n}$ & 109 & 129 \\
\hline
\end{tabular}

\section{Change in Commute Mode}

The survey also asked about the respondent's commute mode at their prior residence. For both the current and prior commute mode, we categorized people according to their most frequent mode. Of the 237 people who reported both commute modes, $13 \%$ switched from commuting primarily by private vehicle to transit and another $12 \%$ switched from private vehicle to walking or bicycling (Table 12 ). In contrast, only $4 \%$ switched from those modes to a private vehicle, indicating that there was a significant shift in commute mode away from private vehicles after moving to the TOD. Without University Pointe, the difference is 
not quite as large, but still positive (Table 13); $9 \%$ switched from private vehicle to transit and $5 \%$ to walk or bike, while $4 \%$ switched from those modes to private vehicle.

Table 12: Changes in Primary Commute Mode from Previous Residence, All TODs

\begin{tabular}{|c|c|c|c|c|c|}
\hline & \multicolumn{4}{|c|}{ New Mode } & \\
\hline Prior Mode & $\begin{array}{l}\text { Private } \\
\text { Vehicle }\end{array}$ & Transit & $\begin{array}{c}\text { Walk or } \\
\text { Bike }\end{array}$ & $\begin{array}{c}\text { Other or } \\
\text { Combination }\end{array}$ & $\mathbf{n}$ \\
\hline Private Vehicle & $32 \%$ & $13 \%$ & $11 \%$ & $6 \%$ & 145 \\
\hline Transit & $2 \%$ & $12 \%$ & $2 \%$ & $0.4 \%$ & 38 \\
\hline Walk Bike & $2 \%$ & $4 \%$ & $7 \%$ & $1 \%$ & 35 \\
\hline $\begin{array}{l}\text { Other or } \\
\text { Combination }\end{array}$ & $2 \%$ & $3 \%$ & $2 \%$ & $1 \%$ & 18 \\
\hline Total & $37 \%$ & $32 \%$ & $22 \%$ & $8 \%$ & 236 \\
\hline
\end{tabular}

Table 13: Changes in Primary Commute Mode from Previous Residence, All TODs excluding University Pointe

\begin{tabular}{|l|c|c|c|c|c|}
\hline & \multicolumn{4}{|c|}{ New Mode } & \\
\hline Prior Mode & $\begin{array}{c}\text { Private } \\
\text { Vehicle }\end{array}$ & Transit & $\begin{array}{c}\text { Walk or } \\
\text { Bike }\end{array}$ & $\begin{array}{c}\text { Other or } \\
\text { Combination }\end{array}$ & n \\
\hline Private Vehicle & $46 \%$ & $9 \%$ & $5 \%$ & $6 \%$ & 103 \\
\hline Transit & $1 \%$ & $10 \%$ & $2 \%$ & $0 \%$ & 21 \\
\hline Walk Bike & $3 \%$ & $4 \%$ & $6 \%$ & $2 \%$ & 23 \\
\hline $\begin{array}{l}\text { Other or } \\
\text { Combination }\end{array}$ & $2 \%$ & $3 \%$ & $1 \%$ & $0 \%$ & 8 \\
\hline Total & $53 \%$ & $26 \%$ & $13 \%$ & $8 \%$ & 155 \\
\hline
\end{tabular}

\section{Use of alternative modes for non-work trips}

The survey asked people how frequently they walked or biked or used transit from home to get to various non-commute destinations in good weather. A separate question also asked the respondent how many times in the last 30 days they (1) took a walk, jog, or stroll around their neighborhood and (2) took a walk from home to a business or store in their neighborhood.

The results from the transit question are shown in Figure 2 for all of the TODs combined. Respondents were most likely to take transit for shopping and eating out, with over $20 \%$ of them doing so once a week or more. 


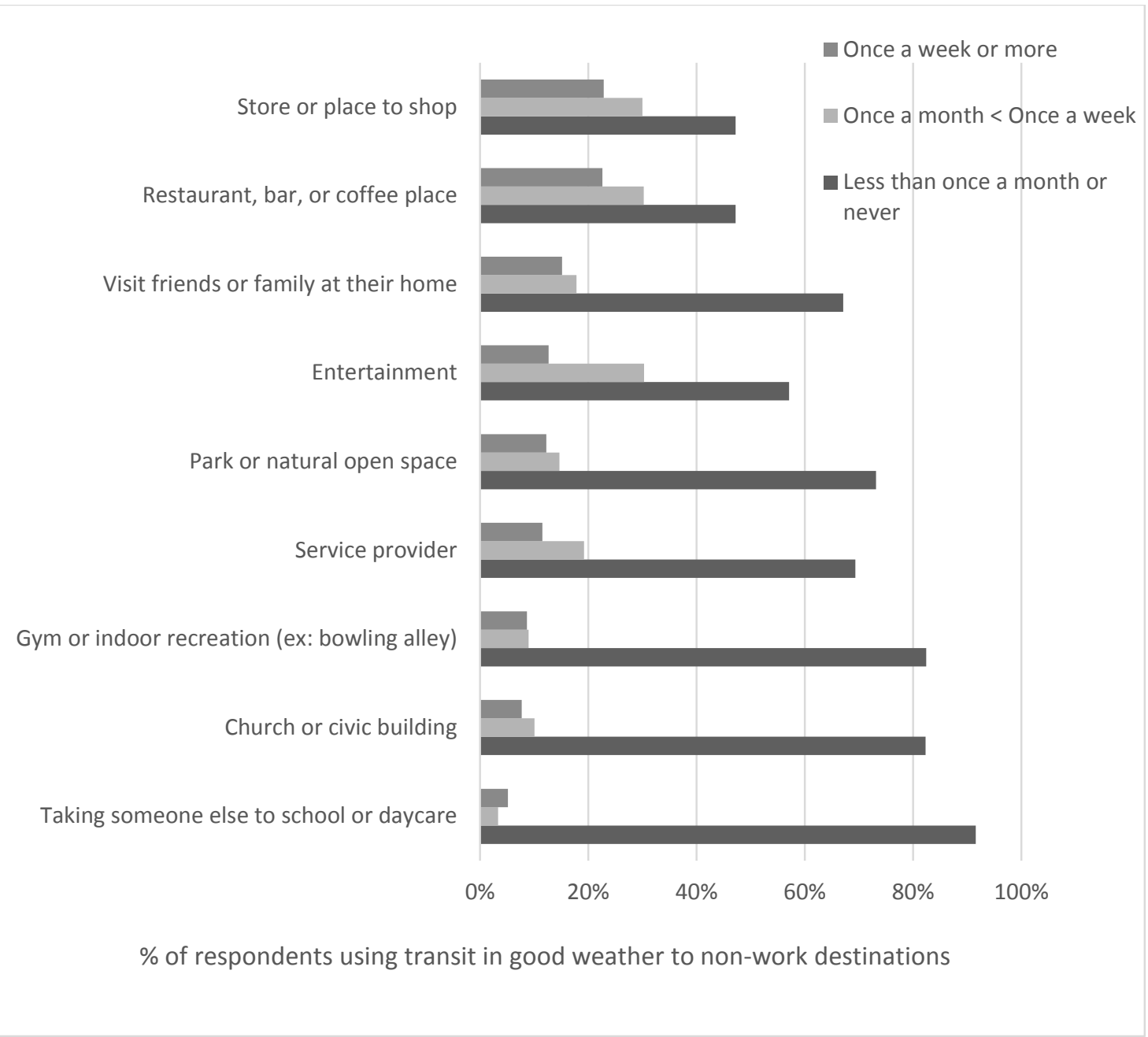

Figure 2: Frequency of taking transit to non-work destinations in good weather

Some of the results for walking and biking, separated by TOD, are shown in Table 14. Over half $(52 \%)$ of the respondents walked or biked from home to a store once a week or more in good weather, while $62 \%$ walked or biked to go out to eat. The table is sorted by the average number of walking trips made from home to nearby businesses in the page 30 days. The differences between the TODs likely reflect the differences in the number of destinations within walking distance in these neighborhoods. 
Table 14: Walking and biking for non-commute purposes

\begin{tabular}{|l|c|c|c|c|c|c|c|}
\hline & $\begin{array}{c}\text { Walks/ } \\
\text { bikes to store } \\
\text { once a week } \\
\text { or more in } \\
\text { good } \\
\text { weather }\end{array}$ & $\begin{array}{c}\text { Walks/ bikes } \\
\text { to restaurant/ } \\
\text { bar/café once } \\
\text { a week or more } \\
\text { in good } \\
\text { weather }\end{array}$ & $\begin{array}{c}\text { Walks/ bikes } \\
\text { with no } \\
\text { destination } \\
\text { once a week or } \\
\text { more in good } \\
\text { weather }\end{array}$ & $\begin{array}{c}\text { Mean \# walk, } \\
\text { jog, or } \\
\text { strolling trips } \\
\text { in } \\
\text { neighborhood } \\
\text { in last 30 days }\end{array}$ & $\begin{array}{c}\text { Mean \# } \\
\text { walking trips } \\
\text { from home } \\
\text { to business } \\
\text { or store in } \\
\text { 1ast 30 days }\end{array}$ & $\begin{array}{c}\text { Mean \# } \\
\text { biking trips } \\
\text { from home } \\
\text { to business } \\
\text { or store in } \\
\text { last 30 days }\end{array}$ & n \\
\hline $\begin{array}{l}\text { Hollywood } \\
\text { Apartments }\end{array}$ & $88 \%$ & $82 \%$ & $53 \%$ & 20.2 & 22.5 & 2.1 & 17 \\
\hline $\begin{array}{l}\text { Central } \\
\text { Eastside } \\
\text { Lofts }\end{array}$ & $46 \%$ & $78 \%$ & $58 \%$ & 17.9 & 17.9 & 3.6 & 27 \\
\hline $\begin{array}{l}\text { University } \\
\text { Pointe }\end{array}$ & $62 \%$ & $63 \%$ & $50 \%$ & 17.7 & 17.8 & 1.5 & 101 \\
\hline Milano & $72 \%$ & $77 \%$ & $68 \%$ & 18.2 & 15.6 & 2.8 & 26 \\
\hline Pettygrove & $61 \%$ & $83 \%$ & $65 \%$ & 19.1 & 13.6 & 3.8 & 24 \\
\hline The Prescott & $35 \%$ & $74 \%$ & $56 \%$ & 20.3 & 11.1 & 3.7 & 57 \\
\hline $\begin{array}{l}\text { Acadia } \\
\text { Gardens }\end{array}$ & $24 \%$ & $22 \%$ & $28 \%$ & 8.8 & 7.7 & 1.6 & 18 \\
\hline $\begin{array}{l}\text { Killingswort } \\
\text { h Station }\end{array}$ & $45 \%$ & $49 \%$ & $23 \%$ & 16.5 & 5.0 & 3.8 & 35 \\
\hline The Knoll & $28 \%$ & $12 \%$ & $17 \%$ & 11.0 & 3.9 & 0.5 & 25 \\
\hline $4^{\text {th }}$ Main & $64 \%$ & $36 \%$ & $46 \%$ & 8.5 & 10.8 & 1.2 & 11 \\
\hline Total & $52 \%$ & $62 \%$ & $47 \%$ & 17.0 & 13.3 & 2.5 & 341 \\
\hline
\end{tabular}

\section{Overall Changes in Travel Modes}

Another question asked about how their daily travel compared to their previous residence:

For this question, please think about your current daily travel and your daily travel when you lived at your previous residence not long before you moved. We would like to know about how your travel has changed, for whatever reason. Please answer for your own travel only.

Overall, the TOD residents claim to be driving less and using transit and walking more than where they used to live (Table 15). Just over half (51\%) claim that they drive a lot less now, $36 \%$ claim they use public transit a lot more now, and $40 \%$ claim they walk a lot more now. About equal shares claim to bike less (29\%) and bike more (24\%). This may reflect shifts from bike to transit or walking. 
Table 15: Use of modes compared to previous residence

\begin{tabular}{|l|c|c|c|c|c|c|}
\hline & $\begin{array}{c}\text { A lot } \\
\text { less now }\end{array}$ & $\begin{array}{c}\text { A little } \\
\text { less now }\end{array}$ & $\begin{array}{c}\text { About } \\
\text { the same }\end{array}$ & $\begin{array}{c}\text { A little } \\
\text { more } \\
\text { now }\end{array}$ & $\begin{array}{c}\text { A lot } \\
\text { more } \\
\text { now }\end{array}$ & n \\
\hline $\begin{array}{l}\text { How much do you drive now, } \\
\text { compared to when you lived at } \\
\text { your previous residence? }\end{array}$ & $\mathbf{5 1 \%}$ & $14 \%$ & $\mathbf{2 7 \%}$ & $5 \%$ & $4 \%$ & 346 \\
\hline $\begin{array}{l}\text { How much do you use public } \\
\text { transit bus or rail) now, compared } \\
\text { to when you lived at your previous } \\
\text { residence? }\end{array}$ & $7 \%$ & $10 \%$ & $\mathbf{2 8 \%}$ & $19 \%$ & $\mathbf{3 6 \%}$ & 343 \\
\hline $\begin{array}{l}\text { How much do you walk in your } \\
\text { neighborhood now, compared to } \\
\text { when you lived at your previous } \\
\text { residence? }\end{array}$ & $7 \%$ & $11 \%$ & $24 \%$ & $20 \%$ & $\mathbf{3 9 \%}$ & 348 \\
\hline $\begin{array}{l}\text { How much do you ride your bike } \\
\text { now, compared to when you lived } \\
\text { at your previous residence? }\end{array}$ & $21 \%$ & $6 \%$ & $\mathbf{4 6 \%}$ & $12 \%$ & $13 \%$ & 327 \\
\hline
\end{tabular}

Notes: Figures above $25 \%$ highlighted in boldface.

\section{Vehicle Ownership and Use}

To see if there were shifts in vehicle ownership caused by moving to the TOD, the survey asked "Did the number of vehicles available for daily travel by your household change as $a$ result of the characteristics of your current neighborhood?" For two-thirds of the respondents, moving did not impact the number of vehicles in the household (Table 16). However, 18\% of the respondents did indicate that they got rid of a vehicle because of the characteristics of the neighborhood, compared with $2 \%$ who got an additional vehicle because of the neighborhood. Another $12 \%$ are considering getting rid of a vehicle. 
Table 16: Change in vehicle ownership after moving

\begin{tabular}{|l|c|}
\hline $\begin{array}{l}\text { No, but I/we are considering getting rid of a vehicle because of the } \\
\text { characteristics of the neighborhood }\end{array}$ & $12 \%$ \\
\hline $\begin{array}{l}\text { No, but I/we are considering getting another vehicle because of the } \\
\text { characteristics of the neighborhood }\end{array}$ & $2 \%$ \\
\hline $\begin{array}{l}\text { No, moving to this place has had no impact on the number of } \\
\text { vehicles }\end{array}$ & $67 \%$ \\
\hline $\begin{array}{l}\text { Yes, I/we got rid of a vehicle because of the characteristics of the } \\
\text { neighborhood }\end{array}$ & $17 \%$ \\
\hline $\begin{array}{l}\text { Yes, I/we got an additional vehicle because of the characteristics of } \\
\text { the neighborhood }\end{array}$ & $2 \%$ \\
\hline $\mathrm{n}$ & 328 \\
\hline
\end{tabular}

\section{Residential Preferences}

One section of the survey attempted to gauge how important various factors were to the respondents in choosing to live in their current home. The question was:

In this question, we'd like to know what was important to you when you were looking for your current residence. Please indicate how important each of the factors was when you were looking for your current residence on a scale from "not at all important" to "extremely important."

The results are shown in Table 17, ranked from most to least important based on the average score. Living near transit was a priority for most of the residents. Well over half (61\%) rated access to MAX as a 3 or 4 on the $1-4$ scale; $37 \%$ did so for access to the Streetcar and $44 \%$ did so for access to busses. 
Table 17: Importance of factors in choosing current residence

\begin{tabular}{|l|c|c|c|}
\hline & Mean & $\begin{array}{c}\text { Std. } \\
\text { Deviatio } \\
\text { n }\end{array}$ & n \\
\hline High quality living unit & 3.4 & 0.7 & 341 \\
\hline Affordable living unit & 3.4 & 0.8 & 340 \\
\hline Easy access to downtown & 3.1 & 0.9 & 337 \\
\hline Shopping areas within walking distance & 3.1 & 0.9 & 340 \\
\hline Amenities in the building & 3.0 & 0.9 & 336 \\
\hline Relatively new living unit & 2.9 & 0.9 & 340 \\
\hline Access to MAX & 2.9 & 1.1 & 339 \\
\hline Low crime rate within neighborhood & 2.8 & 1.0 & 335 \\
\hline Sidewalks throughout the neighborhood & 2.8 & 1.0 & 338 \\
\hline Parks and open spaces nearby & 2.8 & 1.0 & 338 \\
\hline Close to where I work & 2.8 & 1.1 & 331 \\
\hline Attractive appearance of neighborhood & 2.7 & 0.9 & 339 \\
\hline Availability of off-street parking (garages or driveways) & 2.5 & 1.2 & 339 \\
\hline Access to TriMet Busses & 2.5 & 1.2 & 340 \\
\hline Close to friends or family & 2.4 & 1.0 & 337 \\
\hline Lots of people out and about within the neighborhood & 2.4 & 1.0 & 336 \\
\hline Easy access to the freeway & 2.3 & 1.1 & 337 \\
\hline Bike lanes and paths nearby & 2.3 & 1.1 & 337 \\
\hline Economic level of neighbors similar to my level & 2.3 & 1.0 & 333 \\
\hline Low level of car traffic on neighborhood streets & 2.2 & 0.9 & 335 \\
\hline Lots of interaction among neighbors & 2.1 & 0.9 & 336 \\
\hline Access to Streetcar & 2.1 & 1.2 & 339 \\
\hline Access to car share vehicles & 1.6 & 0.9 & 338 \\
\hline High quality K-12 school & 1.3 & 0.7 & 337 \\
\hline
\end{tabular}

Note: Mean scores on a scale of 1-4, 1=Not at all important, 4=Extremely important

Residents were asked about how their current resident differed from their previous residence in terms of size, monthly cost, and commute. Unsurprisingly, the new residences were are generally smaller and more expensive, but also much closer to their work or school. Tables Table 18 to Table 20 show the results of these questions. 
Table 18: Size of current residence compared to prior residence

\begin{tabular}{|l|c|c|c|c|c|c|}
\hline $\begin{array}{l}\text { Is your current residence } \\
\text { smaller or larger (i.e. square } \\
\text { /footage) than your prior } \\
\text { residence? }\end{array}$ & $\begin{array}{c}\text { A lot } \\
\text { smaller }\end{array}$ & $\begin{array}{c}\text { Somewhat } \\
\text { smaller }\end{array}$ & $\begin{array}{c}\text { About } \\
\text { the same } \\
\text { size }\end{array}$ & $\begin{array}{c}\text { Somewhat } \\
\text { larger }\end{array}$ & $\begin{array}{c}\text { A lot } \\
\text { larger }\end{array}$ & n \\
\hline All except University Pointe & $40 \%$ & $29 \%$ & $14 \%$ & $15 \%$ & $2 \%$ & 243 \\
\hline University Pointe & $58 \%$ & $15 \%$ & $10 \%$ & $11 \%$ & $5 \%$ & 97 \\
\hline All & $45 \%$ & $25 \%$ & $13 \%$ & $14 \%$ & $3 \%$ & 340 \\
\hline
\end{tabular}

Table 19: Cost of current residence compared to prior residence

\begin{tabular}{|l|c|c|c|c|c|c|}
\hline $\begin{array}{l}\text { Is your current residence } \\
\text { more expensive or less } \\
\text { expensive / (monthly } \\
\begin{array}{l}\text { costs) than your prior } \\
\text { residence? }\end{array}\end{array}$ & $\begin{array}{c}\text { A lot } \\
\text { more } \\
\text { expensive }\end{array}$ & $\begin{array}{c}\text { Somewhat } \\
\text { more } \\
\text { expensive }\end{array}$ & $\begin{array}{c}\text { About } \\
\text { the same } \\
\text { cost }\end{array}$ & $\begin{array}{c}\text { Somewhat } \\
\text { less } \\
\text { expensive }\end{array}$ & $\begin{array}{c}\text { A lot less } \\
\text { expensive }\end{array}$ & n \\
\hline $\begin{array}{l}\text { All except University } \\
\text { Pointe }\end{array}$ & $29 \%$ & $30 \%$ & $12 \%$ & $20 \%$ & $9 \%$ & 242 \\
\hline University Pointe & $42 \%$ & $23 \%$ & $20 \%$ & $9 \%$ & $6 \%$ & 97 \\
\hline All & $32 \%$ & $28 \%$ & $14 \%$ & $17 \%$ & $8 \%$ & 339 \\
\hline
\end{tabular}

Table 20: Length of commute compared to prior residence

\begin{tabular}{|l|c|c|c|c|c|c|c|}
\hline $\begin{array}{l}\text { Is your commute to } \\
\text { work/school } \\
\text { shorter or longer at } \\
\text { your / current } \\
\text { residence compared } \\
\text { to your prior } \\
\text { residence? }\end{array}$ & $\begin{array}{c}\text { A lot } \\
\text { shorter }\end{array}$ & $\begin{array}{c}\text { Somewhat } \\
\text { shorter }\end{array}$ & $\begin{array}{c}\text { No } \\
\text { difference }\end{array}$ & $\begin{array}{c}\text { Somewhat } \\
\text { longer }\end{array}$ & $\begin{array}{c}\text { A lot } \\
\text { longer }\end{array}$ & $\begin{array}{c}\text { Not } \\
\text { applicable }\end{array}$ & n \\
\hline $\begin{array}{l}\text { All except } \\
\text { University Pointe }\end{array}$ & $25 \%$ & $19 \%$ & $18 \%$ & $15 \%$ & $7 \%$ & $16 \%$ & 239 \\
\hline University Pointe & $51 \%$ & $12 \%$ & $21 \%$ & $5 \%$ & $5 \%$ & $5 \%$ & 98 \\
\hline All & $33 \%$ & $17 \%$ & $19 \%$ & $12 \%$ & $7 \%$ & $4 \%$ & 337 \\
\hline
\end{tabular}

Despite the recognition that the current residences are smaller and more expensive than prior residences, survey respondents generally indicated that the residence did a good job of meeting their current needs. Asked how well the residence and its location met the current needs of their household, nearly three-quarters of respondents indicate that the residence met their needs "well" or "very well" across four different criteria including the location of the neighborhood, the characteristics of the neighborhood, the location of the building 
within the neighborhood, and the characteristics of the residence itself. The results of these questions are shown in Table 21.

Table 21: How the TODs meet residents' needs

\begin{tabular}{|c|c|c|c|c|c|c|c|}
\hline \multicolumn{2}{|c|}{$\begin{array}{l}\text { How well do you think your residence } \\
\text { and its location meet the current needs of } \\
\text { your household? }\end{array}$} & $\begin{array}{l}\text { Very } \\
\text { poorly }\end{array}$ & Poorly & $\begin{array}{l}\text { Neither } \\
\text { poorly } \\
\text { nor } \\
\text { well }\end{array}$ & Well & $\begin{array}{l}\text { Very } \\
\text { well }\end{array}$ & $\mathbf{n}$ \\
\hline \multirow{2}{*}{$\begin{array}{l}\text { Location of your } \\
\text { neighborhood in } \\
\text { the region }\end{array}$} & $\begin{array}{l}\text { All except } \\
\text { University Pointe }\end{array}$ & $0.4 \%$ & $2 \%$ & $9 \%$ & $33 \%$ & $55 \%$ & 244 \\
\hline & University Pointe & $1 \%$ & $2 \%$ & $7 \%$ & $34 \%$ & $56 \%$ & 99 \\
\hline \multirow{2}{*}{$\begin{array}{l}\text { Characteristics of } \\
\text { the neighborhood } \\
\text { itself }\end{array}$} & $\begin{array}{l}\text { All except } \\
\text { University Pointe }\end{array}$ & $2 \%$ & $8 \%$ & $16 \%$ & $40 \%$ & $34 \%$ & 242 \\
\hline & University Pointe & $0 \%$ & $5 \%$ & $22 \%$ & $39 \%$ & $34 \%$ & 99 \\
\hline \multirow{2}{*}{$\begin{array}{l}\text { Location of your } \\
\text { residence within } \\
\text { your neighborhood }\end{array}$} & $\begin{array}{l}\text { All except } \\
\text { University Pointe }\end{array}$ & $1 \%$ & $7 \%$ & $11 \%$ & $41 \%$ & $41 \%$ & 243 \\
\hline & University Pointe & $0 \%$ & $0 \%$ & $12 \%$ & $37 \%$ & $51 \%$ & 98 \\
\hline \multirow{2}{*}{$\begin{array}{l}\text { Characteristics of } \\
\text { the residence itself }\end{array}$} & $\begin{array}{l}\text { All except } \\
\text { University Pointe }\end{array}$ & $2 \%$ & $3 \%$ & $10 \%$ & $43 \%$ & $42 \%$ & 243 \\
\hline & University Pointe & $8 \%$ & $2 \%$ & $15 \%$ & $42 \%$ & $33 \%$ & 98 \\
\hline
\end{tabular}

\section{Travel Preferences}

Some recent research examining the links between land use, urban form, and travel behavior has found that people's attitudes and preferences regarding travel can significantly influence decisions. To help examine this further, the survey included a set of questions about travel preferences:

We'd like to ask about your preferences with respect to daily travel. Please indicate the extent to which you agree or disagree with each of the following statements on a scale from "strongly disagree" to "strongly agree." There are no right and wrong answers; we want only your true opinions.

Respondents ranked a series of statements from "strongly disagree" (1) to "strongly agree" (5). The results are shown in Table 22, sorted based on the statements respondents agreed with most strongly. The results show that these respondents place a high priority on walking and minimizing their travel. 
Table 22: Travel preferences of TOD residents

\begin{tabular}{|c|c|c|c|}
\hline & Mean & $\begin{array}{l}\text { Std. } \\
\text { Dev. }\end{array}$ & $\mathbf{n}$ \\
\hline I like walking & 4.1 & 0.9 & 333 \\
\hline I prefer to organize my errands so that I make as few trips as possible & 4.0 & 0.9 & 332 \\
\hline Walking can sometimes be easier for me than driving & 3.9 & 1.2 & 334 \\
\hline $\begin{array}{l}\text { When I need to buy something, I usually prefer to get it at the closest } \\
\text { store possible }\end{array}$ & 3.7 & 1.0 & 332 \\
\hline I prefer to walk rather than drive whenever possible. & 3.6 & 1.1 & 332 \\
\hline Public transit can sometimes be easier for me than driving & 3.5 & 1.3 & 327 \\
\hline $\begin{array}{l}\text { I often use the telephone or the Internet to avoid having to travel } \\
\text { somewhere }\end{array}$ & 3.4 & 1.1 & 333 \\
\hline The trip to/from work is a useful transition between home and work & 3.4 & 0.9 & 325 \\
\hline I use my trip to/from work productively & 3.3 & 1.1 & 326 \\
\hline I like driving & 3.3 & 1.2 & 331 \\
\hline I like taking transit & 3.3 & 1.1 & 329 \\
\hline I need a car to do many of the things I like to do & 3.3 & 1.3 & 333 \\
\hline I try to limit my driving to help the environment & 3.3 & 1.2 & 331 \\
\hline I prefer to take transit rather than drive whenever possible & 3.2 & 1.3 & 332 \\
\hline I like riding a bike & 3.2 & 1.4 & 329 \\
\hline Getting to work without a car is a hassle & 3.0 & 1.4 & 326 \\
\hline $\begin{array}{l}\text { We could manage pretty well with one fewer car than we have (or with } \\
\text { no car) }\end{array}$ & 2.9 & 1.3 & 331 \\
\hline Biking can sometimes be easier for me than driving & 2.8 & 1.3 & 328 \\
\hline I prefer to bike rather than drive whenever possible & 2.7 & 1.3 & 330 \\
\hline The only good thing about traveling is arriving at your destination & 2.6 & 1.1 & 334 \\
\hline Traveling by car is safer overall than walking & 2.6 & 1.1 & 332 \\
\hline I would like to own at least one more car & 2.1 & 1.3 & 331 \\
\hline
\end{tabular}

Note: Mean scores on a scale of 1-5, 1=strongly disagree, $5=$ strongly agree, $3=$ neutral. 


\section{Demographics}

Some of the demographics of the respondents are summarized in Table 23. A majority of the respondents were women, and few of the households had children. Some of the respondents indicated travel limitations.

Table 23: Respondent demographics

\begin{tabular}{|l|c|c|c|c|c|}
\hline & $\begin{array}{c}\text { Average \# } \\
\text { people per } \\
\text { household }\end{array}$ & $\begin{array}{c}\text { \% of homes } \\
\text { with people } \\
\text { under 16 }\end{array}$ & $\begin{array}{c}\text { \% of } \\
\text { respondents } \\
\text { over 64 }\end{array}$ & \% female & n \\
\hline Acadia Gardens & 2.2 & $41 \%$ & $0 \%$ & $67 \%$ & 18 \\
\hline Central Eastside Lofts & 2.0 & $7 \%$ & $0 \%$ & $50 \%$ & 26 \\
\hline Hollywood Apartments & 1.4 & $0 \%$ & $0 \%$ & $38 \%$ & 16 \\
\hline Killingsworth Station & 1.3 & $0 \%$ & $12 \%$ & $58 \%$ & 33 \\
\hline Milano & 1.6 & $5 \%$ & $0 \%$ & $32 \%$ & 25 \\
\hline Pettygrove & 1.6 & $0 \%$ & $0 \%$ & $46 \%$ & 26 \\
\hline The Knoll & 1.1 & $0 \%$ & $67 \%$ & $72 \%$ & 25 \\
\hline The Prescott & 1.5 & $0 \%$ & $2 \%$ & $49 \%$ & 57 \\
\hline $4^{\text {th }}$ Main & 1.6 & $0 \%$ & $9 \%$ & $64 \%$ & 10 \\
\hline University Pointe & & & $0 \%$ & $71 \%$ & 97 \\
\hline Total & 1.5 & $4 \%$ & $7 \%$ & $57 \%$ & 333 \\
\hline
\end{tabular}

The economic characteristics of the respondents and their households are shown in Table 24 and Table 25. The respondents not living at University Pointe were generally of moderate income and well-educated. On average, the households have fewer than one vehicle per person of driving age (at 0.2 cars per individual in University Pointe and 0.77 cars per household at all other TODs surveyed). In comparison, one study of TODs found average household car ownership generally in the range of 0.5 to 1.3 cars per household in various TODs, while another found TODs averaged 0.9 cars per household compared to 1.6 for non-TOD households (TCRP 128, pg. 34). The average cars per household in Portland, according to 2013 ACS 1 year data, is about 1.44, nearly twice the rate of the surveyed TODs.

Table 25 compares the income distribution to that of the cities of Hillsboro, Portland, and Tigard, along with zip code 97086 (Unincorporated Clackamas County \& Happy Valley). While University Pointe residents were more likely to be in the lowest income bracket, residents in the other TODs were slightly less likely to be in the highest or lowest income brackets than the general populations of the cities in which they reside. 
Table 24: Household income, education and vehicle availability

\begin{tabular}{|l|c|c|c|c|c|}
\hline & $\begin{array}{c}\text { Median Income } \\
\text { (category) }\end{array}$ & $\begin{array}{c}\text { \% of } \\
\text { respondents } \\
\text { with income } \\
\text { under \$25,000 }\end{array}$ & $\begin{array}{c}\text { \% of } \\
\text { respondents } \\
\text { with 4-year } \\
\text { college degree }\end{array}$ & $\begin{array}{c}\text { Average number } \\
\text { of vehicles per } \\
\text { person 16 or } \\
\text { older }\end{array}$ & $\mathbf{n}$ \\
\hline $\begin{array}{l}\text { University } \\
\text { Pointe }\end{array}$ & $\begin{array}{c}\text { Less than } \\
\$ 15,000\end{array}$ & $83 \%$ & $26 \%$ & 0.20 & 97 \\
\hline All other TODs & $\$ 50,000-74,999$ & $22 \%$ & $66 \%$ & 0.77 & 236 \\
\hline Total & $\$ 35,000-49,999$ & $40 \%$ & $54 \%$ & 0.59 & 333 \\
\hline
\end{tabular}

Table 25: Household income of respondents, compared to 2009-2013 American Community Survey data

\begin{tabular}{|l|r|r|r|r|r|r|}
\hline & Univ. & $\begin{array}{c}\text { Zipcode } \\
\text { other } \\
\text { TODs }\end{array}$ & $\begin{array}{c}\text { 97086 } \\
\text { (Clackamas } \\
\text { \& Happy } \\
\text { Valley) }\end{array}$ & Hillsboro & Portland & Tigard \\
\hline Less than $\$ 15,000$ & $65 \%$ & $5 \%$ & $8 \%$ & $8 \%$ & $14 \%$ & $7 \%$ \\
\hline$\$ 15,000-\$ 24,999$ & $18 \%$ & $17 \%$ & $5 \%$ & $8 \%$ & $10 \%$ & $10 \%$ \\
\hline$\$ 25,000-\$ 34,999$ & $4 \%$ & $11 \%$ & $10 \%$ & $9 \%$ & $10 \%$ & $11 \%$ \\
\hline$\$ 35,000-\$ 49,999$ & $6 \%$ & $13 \%$ & $11 \%$ & $12 \%$ & $13 \%$ & $13 \%$ \\
\hline$\$ 50,000-\$ 74,999$ & $4 \%$ & $22 \%$ & $17 \%$ & $20 \%$ & $17 \%$ & $16 \%$ \\
\hline$\$ 75,000-\$ 99,999$ & $1 \%$ & $14 \%$ & $14 \%$ & $17 \%$ & $12 \%$ & $14 \%$ \\
\hline$\$ 100,000-\$ 149,999$ & $0 \%$ & $15 \%$ & $19 \%$ & $16 \%$ & $13 \%$ & $17 \%$ \\
\hline$\$ 150,000$ and over & $1 \%$ & $4 \%$ & $16 \%$ & $9 \%$ & $10 \%$ & $12 \%$ \\
\hline $\mathrm{n}$ & 95 & 227 & 9,383 & 32,594 & 250,133 & 19,214 \\
\hline
\end{tabular}

\section{Conclusions}

The survey results indicate that the TOD residents are using transit for commuting significantly more than residents of Portland, Hillsboro, and Tigard, and zip code 97086. The difference is likely due to a combination of factors, including the location of sites near transit, shorter commute times, vehicle ownership, and travel preferences of residents. In addition, it appears that residents of these TODs are generating significantly fewer vehicle trips per unit than assumed by using standard trip generation factors. This difference may be due to the demographics of the residents, which were more likely to be students or retired, and were less likely to own vehicles compared to the city population and previous TOD 
surveys. Good public transit access was an important factor for most of the residents in choosing their current home.

A few key findings have emerged from the analysis done so far:

- Travel patterns of University Pointe residents are significantly different from those of other TOD residents. In particular, the University Pointe residents made far fewer trips in motor vehicles and made far more trips by walking and bicycling. These differences are expected since most residents are students attending Portland State University.

- Vehicle availability helps explain transit use. TOD residents in households with less than one vehicle per driver were far more likely to use transit (and far less likely to travel via private vehicles). However, the relationship may not be as simple as it appears. Seventeen percent of the respondents indicated that they got rid of a vehicle because of the characteristics of the neighborhood. Therefore, a share of the households with limited vehicle availability may have consciously chosen to have fewer vehicles because they could use transit or walk instead.

- Employed residents at the TODs are commuting regularly on transit at a higher rate (26\%) than for all workers in the City of Portland (13\%), Hillsboro (7\%), Tigard (6\%), and in zip code 97086 (4\%). This finding reflects, in part, the proximity of the TODs to high-quality transit service.

- Parking pricing influences commute mode split. Respondents who did not have to pay to park at work or school were far more likely to drive to work.

- Moving to the TOD resulted in a net shift to increased transit commuting.

- Respondents indicate that they are driving less and using transit more now compared to their previous residence.

- Many TOD residents have opted to live in smaller residences at greater monthly cost in exchange for a shorter commute and living in a location and unit that suits their needs. 


\section{Appendix: Trip Generation Rates for Transit-Oriented Development}

\section{Part 1: ITE Trip Generation Manual Rates}

We conducted background research on contemporary trip generation estimates for similar types of buildings to those surveyed in this project. The Institute of Transportation Engineers Trip Generation Manual (TGM), 9th Edition (2012), contains motor vehicle data based on "trip generation studies submitted voluntarily to ITE by public agencies, developers, consulting firms and associations." A selection of residential building types representing the best comparable examples to the Metro study are shown in Table 26, along with a few characteristics of the studies including in the TGM for each building type.

Table 26 ITE Trip Generation Manual Comparable Residential Building Categories

\begin{tabular}{|c|c|c|c|c|c|}
\hline $\begin{array}{l}\text { ITE } \\
\text { Code }\end{array}$ & Name & Description & Metro Study TODs & $\begin{array}{l}\text { \# of ITE } \\
\text { studies }\end{array}$ & $\begin{array}{l}\text { ITE study } \\
\text { Years }\end{array}$ \\
\hline 210 & $\begin{array}{l}\text { Single } \\
\text { Family } \\
\text { Detached }\end{array}$ & & none & $50+$ & $\begin{array}{l}\text { late } 1960 \text { s to } \\
2000 \text { s }\end{array}$ \\
\hline 220 & Apartment & $\begin{array}{l}\text { \# levels not } \\
\text { specified }\end{array}$ & none & 33 & $\begin{array}{l}\text { late } 1960 \text { s to } \\
2000 \text { s }\end{array}$ \\
\hline 221 & $\begin{array}{l}\text { Low Rise } \\
\text { Apt. }\end{array}$ & 1 or 2 levels & none & 13 & $\begin{array}{l}\text { early 1970s to } \\
\text { late 1990s }\end{array}$ \\
\hline 222 & $\begin{array}{l}\text { High Rise } \\
\text { Apt. }\end{array}$ & $\begin{array}{l}10 \text { or more } \\
\text { levels }\end{array}$ & University Pointe & 9 & $\begin{array}{l}\text { late } 1960 \text { s to } \\
\text { late } 1980 \text { s }\end{array}$ \\
\hline 223 & $\begin{array}{l}\text { Mid Rise } \\
\text { Apt. }\end{array}$ & 3-9 levels & $\begin{array}{l}\text { Central Eastside Lofts, } \\
\text { Milano, Prescott, } \\
\text { Pettygrove, Acadia, } \\
\text { 4th Main }\end{array}$ & 1 & late $1980 \mathrm{~s}$ \\
\hline 230 & $\begin{array}{l}\text { Condo/ } \\
\text { Townhouse }\end{array}$ & $\begin{array}{l}\text { \# of levels not } \\
\text { specified }\end{array}$ & none & 25 & late $1980 \mathrm{~s}$ \\
\hline 231 & $\begin{array}{l}\text { Low Rise } \\
\text { Condo/ } \\
\text { Townhouse } \\
\end{array}$ & $\begin{array}{l}1-2 \text { levels } \\
\text { condo or } \\
\text { townhouse }\end{array}$ & none & 5 & $\begin{array}{l}\text { late } 1970 \text { s to } \\
2000 \mathrm{~s}\end{array}$ \\
\hline 232 & $\begin{array}{l}\text { High Rise } \\
\text { Condo/ } \\
\text { Townhouse }\end{array}$ & $\begin{array}{l}+ \text { levels } \\
\text { condor or } \\
\text { townhouse }\end{array}$ & Hollywood, K Station & 5 & $\begin{array}{l}\text { 1980s and } \\
1990 \text { s }\end{array}$ \\
\hline 251 & $\begin{array}{l}\text { Senior Adult } \\
\text { detached }\end{array}$ & & none & 10 & 1980 s to $2000 \mathrm{~s}$ \\
\hline 252 & $\begin{array}{l}\text { Senior Adult } \\
\text { Housing } \\
\text { Attached }\end{array}$ & & Knoll & 8 & 1980 s to $2000 \mathrm{~s}$ \\
\hline
\end{tabular}


The $9^{\text {th }}$ Edition of the TGM does not account for any building-specific or geographic traits that might be related to being "transit-oriented" other than the categories shown in the first column of Table 26. As evidenced by the final column in Table 1, the studies included in the manual are considerably dated in most cases. Despite these limitations, the available data do show that certain building types generate differing levels of motor vehicle trips. Table 27 shows the average, low, and high trip generation rates for studies included in each TGM category shown, along with the standard deviation. Daily rates were not available for mid-rise apartments; however based on peak hour trips, mid-rise apartments appear to be similar to high-rise apartments (both generated an average of 0.3 trips in an AM peak hour), and high-rise condos.

Table 27 Trip Generation per Dwelling Unit on a Weekday

\begin{tabular}{|l|l|c|c|c|c|c|c|c|c|}
\hline & & \multicolumn{3}{|c|}{ Daily Trips } & \multicolumn{3}{c|}{ AM Peak Hour } \\
\hline Code & Name & Average & Low & High & $\begin{array}{l}\text { Standard } \\
\text { Deviation }\end{array}$ & Average & Low & High & $\begin{array}{c}\text { Standard } \\
\text { Deviation }\end{array}$ \\
\hline 210 & $\begin{array}{l}\text { Single } \\
\text { Family } \\
\text { Detached }\end{array}$ & 9.52 & 4.31 & 21.85 & 3.7 & 0.75 & 0.33 & 2.27 & 0.9 \\
\hline 220 & Apartment & 6.65 & 1.27 & 12.5 & 3.07 & 0.51 & 0.1 & 1.02 & 0.73 \\
\hline 221 & $\begin{array}{l}\text { Low Rise } \\
\text { Apt. }\end{array}$ & 6.59 & 5.1 & 9.24 & 2.84 & 0.46 & 0.25 & 0.86 & 0.7 \\
\hline 222 & $\begin{array}{l}\text { High Rise } \\
\text { Apt. }\end{array}$ & 4.2 & 3 & 6.45 & 2.32 & 0.3 & 0.18 & 0.47 & 0.55 \\
\hline 223 & $\begin{array}{l}\text { Mid Rise } \\
\text { Apt. }\end{array}$ & $\mathrm{n} / \mathrm{a}$ & $\mathrm{n} / \mathrm{a}$ & $\mathrm{n} / \mathrm{a}$ & $\mathrm{n} / \mathrm{a}$ & 0.3 & 0.06 & 0.46 & 0.56 \\
\hline 230 & $\begin{array}{l}\text { Condo/ } \\
\text { Townhouse }\end{array}$ & 5.81 & 1.53 & 11.79 & 3.11 & 0.44 & 0.15 & 1.61 & 0.69 \\
\hline 231 & $\begin{array}{l}\text { Low Rise } \\
\text { Condo/ } \\
\text { Townhouse }\end{array}$ & $\mathrm{n} / \mathrm{a}$ & $\mathrm{n} / \mathrm{a}$ & $\mathrm{n} / \mathrm{a}$ & $\mathrm{n} / \mathrm{a}$ & 0.67 & 0.33 & 0.82 & 0.83 \\
\hline 232 & $\begin{array}{l}\text { High Rise } \\
\text { Condo/ } \\
\text { Townhouse }\end{array}$ & 4.18 & 3.91 & 4.93 & 2.08 & 0.34 & 0.31 & 0.48 & 0.59 \\
\hline 251 & $\begin{array}{l}\text { Senior Adult } \\
\text { detached }\end{array}$ & 3.68 & 2.9 & 5.7 & 2.04 & 0.22 & 0.13 & 0.84 & 0.47 \\
\hline $\begin{array}{l}\text { Senior Adult } \\
\text { Housing } \\
\text { Attached }\end{array}$ & 3.44 & 2.59 & 4.79 & 1.93 & 0.2 & 0.06 & 0.27 & 0.45 \\
\hline
\end{tabular}

Source: ITE Trip Generation Manual, $9^{\text {th }}$ Edition, 2012.

Based on available TGM data, the number of trips generated by TOD buildings similar to those in the 2014 Metro study would be expected to be closer to the 4.2 to 4.18 trips of the high-rise apartment or high-rise condo categories, respectively, than to the 6.65 daily rate for the "apartment" category (of unspecified height), or the 6.59 of the more specific "low rise apartment" category. 


\section{Part 2: "Smart Growth Trip-Generation Adjustment" Tool}

A recent project by a team lead by UC Davis sought to calculate more accurate trip generation numbers for "smart growth" projects using inputs including TGM trip rates, information about the area surrounding the building, transit access, walking and bicycling facilities, amount of surface parking, and distance from the $\mathrm{CBD}$, among others. The team created a tool which designed to replicate actual trip rates identified for a series of smart growth projects through a study. More details about the study and tool can be found online at http://ultrans.its.ucdavis.edu/projects/smart-growth-trip-generation.

Applicability of the UC Davis tool as based on meeting the following criteria:

- Land Use: The model applies mid- to high-density residential (ITE Trip Generation Manual Land Use Codes 220, 222, 223, 230, 232), office (710), restaurant (925, 931), and coffee/donut shop (936);

- Population and Jobs: $\mathrm{J}>4000$ and $\mathrm{R}>(6900-0.1 \mathrm{~J})$, where $\mathrm{J}$ is the number of jobs within a 0.5 -mile radius of the site and $\mathrm{R}$ is the number of residents within a 0.5 -mile radius of the site;

- Transit: There are a total of $>=10$ bus stop locations on all bus lines that pass within any part of a 0.25 -mile radius around the study site during a typical weekday PM peak hour or a total of $>=5$ individual train stop locations on all train lines that pass within any part of a 0.5 -mile radius around the study site during a typical weekday PM peak hour;

- Bike and Sidewalk: It is recommended that the tool be applied only at sites that meet at least 1 of the 2 following smart-growth pedestrian or bicycle criteria: 1) There is at least one designated bicycle facility within two blocks of the edge of the site (designated bicycle facilities include multi-use trails, cycle tracks, and bicycle lanes; they do not include shared lane markings or basic bicycle route signs with no other facilities); 2) There is $>50 \%$ sidewalk coverage on streets within a 0.25 -mile radius of the site; and

- Overall: Meets all of the above criteria.

As shown in Table 28, only College Station meets all the eligibility criteria for the tool. The Knoll did not meet the land use criteria, as senior housing was not tested in the data collection process for the project. All of the other building locations either had insufficient population or job density in the surrounding area, or did not have adequate transit access to qualify. It may be worth noting here that the study was focused on "smart-growth" specifically, and not "transit-oriented" development. As such, a building might well be transit-oriented, but not qualify as a smart growth building according to the standards set forth in the project. Despite this limitation, we applied the model to all of the surveyed sites, with the results in Table 29. Our estimated rates are lower than the rates adjusted from ITE using the UC Davis methodology. 
Table 28 Applicability of Davis Model to Portland Metro TOD projects

\begin{tabular}{|l|c|c|c|c|c|}
\hline & \multicolumn{5}{|c|}{ Model Applicability } \\
\hline \multicolumn{1}{|c|}{ Development } & Overall & Land use & $\begin{array}{c}\text { Population } \\
\text { and Jobs }\end{array}$ & Transit & $\begin{array}{c}\text { Bike and } \\
\text { Sidewalk }\end{array}$ \\
\hline $\begin{array}{l}\text { College Station - } \\
\text { University Pointe }\end{array}$ & $\checkmark$ & $\checkmark$ & $\checkmark$ & $\checkmark$ & $\checkmark$ \\
\hline The Knoll & & & & $\checkmark$ & $\checkmark$ \\
\hline $\begin{array}{l}\text { Central Eastside } \\
\text { Lofts }\end{array}$ & & $\checkmark$ & & & $\checkmark$ \\
\hline Milano & $\checkmark$ & & $\checkmark$ & $\checkmark$ \\
\hline $\begin{array}{l}\text { Hollywood } \\
\text { Apartments }\end{array}$ & & $\checkmark$ & $\checkmark$ & & $\checkmark$ \\
\hline The Prescott & $\checkmark$ & & & $\checkmark$ \\
\hline $\begin{array}{l}\text { Killingsworth } \\
\text { Station (K Station) }\end{array}$ & & $\checkmark$ & & & $\checkmark$ \\
\hline Pettygrove & & $\checkmark$ & $\checkmark$ & & $\checkmark$ \\
\hline Acadia Gardens & & $\checkmark$ & & & $\checkmark$ \\
\hline $\begin{array}{l}\text { Hillsboro 4th and } \\
\text { Main }\end{array}$ & & $\checkmark$ & & & $\checkmark$ \\
\hline
\end{tabular}

Table 29 ITE Peak Rates and UC Davis Model Adjustment

\begin{tabular}{|l|c|c|c|c|}
\hline \multicolumn{1}{|c|}{ Development } & $\begin{array}{c}\text { Average } \\
\text { Adjustment } \\
\text { (Actual/ITE) }\end{array}$ & $\begin{array}{c}\text { ITE Daily } \\
\text { Rate }\end{array}$ & $\begin{array}{c}\text { "Smart } \\
\text { Growth" } \\
\text { Adjusted } \\
\text { Rate }\end{array}$ & $\begin{array}{c}\text { PSU } \\
\text { Survey } \\
\text { Rate }\end{array}$ \\
\hline $\begin{array}{l}\text { College Station - } \\
\text { University Pointe }\end{array}$ & $35 \%$ & 4.2 & 1.4 & 0.34 \\
\hline The Knoll & $75 \%$ & 3.4 & 2.6 & 1.1 \\
\hline Central Eastside Lofts & $68 \%$ & 4.2 & 2.8 & 1.6 \\
\hline Milano & $67 \%$ & 4.2 & 2.8 & 1.1 \\
\hline Hollywood Apartments & $72 \%$ & 4.18 & 3.0 & 1.8 \\
\hline The Prescott & $69 \%$ & 4.2 & 2.9 & 2.1 \\
\hline $\begin{array}{l}\text { Killingsworth Station } \\
\text { (K Station) }\end{array}$ & $73 \%$ & 4.18 & 3.0 & 1.3 \\
\hline Pettygrove & $70 \%$ & 4.2 & 2.9 & 2.3 \\
\hline Acadia Gardens & $75 \%$ & 4.2 & 3.2 & 2.5 \\
\hline Hillsboro 4th and Main & $74 \%$ & 4.2 & 3.1 & 0.9 \\
\hline
\end{tabular}

